\title{
Growth Changes Induced by Gamma Radiation on Biomphalaria straminea (Dunker, 1848)
}

\author{
Mauricy A da Motta ${ }^{+}$, Maria Teresa J Catanho, Ana MMA Melo
}

Departamento de Biofísica e Radiobiologia, Universidade Federal de Pernambuco, Av. Prof. Moraes Rego s/nํㅡ, 50670-420 Recife, PE, Brasil

Doses of ${ }^{60}$ Co gamma radiation with $2.5 ; 5 ; 7.5 ; 10 ; 15 ; 20 ; 25 ; 30 ; 35 ; 40 ; 45 ; 50 ; 55 ; 60 ; 80 ; 160$; 320 and 640 Gy were applied to 1,080 snails Biomphalaria straminea, an intermediate host of Schistosoma mansoni, divided in groups containing 30 mollusks. In addition, 60 non irradiated snails were kept as control. Fifty percent of the population was kept in colonies (allowing cross fertilization) while the other half was maintained in sexual isolation (allowing self fertilization) and during one month their growth was observed through the daily measurement of the shell diameter. Results showed that after 20 Gy doses the growth in shell diameter of irradiated snails was greater than that of the control group after 30 days. At this dose the snail size was the greatest, among all isolated groups. The 80 Gy doses also induced the final shell diameter of isolated snails to be greater then that observed in the control groups. As this effect was most evident among the isolated snails, a possible hormonal role may have been involved in the observed phenomena, which is under investigation with the objective of identifying any future applications that this could have to schistosomiasis control.

Key words: growth - gamma radiation - Biomphalaria straminea - snails

Schistosoma mansoni is widespread in the northeast of Brazil, reportedly brought from Africa by the slaves (Malta 1994). It also exists in other regions and causes endemic schistosomiasis, a tropical disease that can bring about spleen and liver hypertrophy, digestive bleeding and other circulatory complications known as Banti syndrome.

Biomphalaria are hermaphrodite snails (Paraense \& Deslandes 1955, Leal 1976) and their species glabrata, straminea and tenagophila (Paraense \& Deslandes 1955) exist in Brazil. These snails are intermediate hosts for $S$. mansoni with $B$. straminea being prevalent in many regions of Brazil (Paraense \& Deslandes1955, Leal 1976).

The embryological development of snails is particularly affected by ionizing radiation as stated by Liard et al. (1968), Okazaki et al. (1996), Melo et al. (1996) and Melo (1998). A previous report stated that following irradiation with gamma rays, a cessation in the development of the shell may occur (Perlowagora-Szumlewicz \& Berry 1964). Snails of different ages showed the same shell diameter as observed by Rey (1967), Leal (1976), Rozenberg (1989) and Carvalho (1992) .

\footnotetext{
${ }^{+}$Corresponding author. Fax: +55-81-271.8560. E-mail: motta@npd.ufpe.br Received 31 March 1999 Accepted 5 August 1999
}

In order to study controversial aspects in $B$. straminea shell development following exposure to ionizing radiation, the growing behavior of this epidemiological vector of schistosomiasis after exposure to low intensity gamma rays was studied, in colonies (cross fertilization) and sexually segregated (self fertilization) situations.

\section{MATERIALS AND METHODS}

A population of 1,080 snails of $B$. straminea, BH breed obtained from Centro de Pesquisas Aggeu Magalhães-Fiocruz, was exposed to gammarays obtained from a ${ }^{60}$ Co source receiving doses of $2.5 ; 5 ; 7.5 ; 10 ; 15 ; 20 ; 25 ; 30 ; 35 ; 40 ; 45 ; 50 ; 55 ; 60$; $80 ; 160 ; 320$ and $640 \mathrm{~Gy}$, applied to groups of 30 snails per dose. An additional group of 60 non irradiated (0 Gy) snails was kept as control.

The mollusks were bred from eggs laid with a maximal difference of two days and were raised in laboratory for approximately 50 days. All snails were in a reproductive development stage.

Fifty percent of the studied population was kept in colonies and the other half was maintained isolated in sexual segregation, allowing cross fertilization and self fertilization, respectively, in each set. Consequently, the snail in each groups/dose were placed in individual (isolated) and collective (colony) aquariums with the ratio of water volume/ snail $(50 \mathrm{ml})$ kept constantly replenished with water $\left(25^{\circ} \mathrm{C} \pm 2^{\circ} \mathrm{C}\right.$ and $\mathrm{pH}$ 6.6-6.8) during the period of observation.

The irradiation of the snails by gamma-rays was done with groups of 30 snails held inside glass 
tubes by dose and placed in gamma-cell irradiator, model RL-60, from Radionics Laboratory, with dose rate of 0.97 Gy per minute. In order to avoid copulation during the exposure time, the snails were separated by a thin cotton cushion, in the isolated set of mollusks. The control group remained in a dark environment for the same time as the maximal (640 Gy) irradiation was applied in order to have the same conditions of temperature and humidity as those used in the irradiation procedure.

The diameter was measured daily by means of a caliper applied to the major shell diameter, with the sites used for measuring marked with white ink.

\section{RESULTS}

The resulting data of the major shell snail diameter - after 30 days per dose group - were normalized as percentage as shown in the Table, with the slope of the regression line of the development during one month. Therefore, any individual differences in size before irradiation were equalized and the rate of growth is directly displayed.

The data obtained reflect an augmented shell diameter after 30 days of observation. The control group showed a greater increment in shell diameter than the colonized one. The rate of development was also higher in isolated control snails, as shown by the slope of the regression lines. This finding agrees with other physiological processes enhanced by ionizing radiation (Carvalho 1992, Motta 1997a) of snails. After gamma rays irradiation of the two experimental groups, the highest growth rate - compared to the control group - was observed in the 20 Gy dose-group, as indicated by the slope seen in the Table. Irradiation with $40 \mathrm{~Gy}$ induced a mild growth change only among the isolated group.

Another shift in the growth rate was detected after a dose of $80 \mathrm{~Gy}$, but this was less intense than the peak induced by $20 \mathrm{~Gy}$, among both colonized and segregated snails.

All the colonized snails from the $320 \mathrm{~Gy}$ and 640 Gy dose-groups died after 18 and 19 days from its irradiation, respectively. The isolated snails from the 160,320 and 640 Gy dose-groups also died at the 23 rd 19th and 12th day after irradiation. This circumstance makes the statistical analysis using the regression lines ineffective, due to the artifacts introduced into the data which lead to a distorted evaluation of the developmental behavior of the survivors. Therefore, the data from the above mentioned dose-groups were not included in the graphic representation of the phenomenon displayed in the Figure. The difference observed between the two groups showed a statistical significance $p<0.001$, after analysis using the Student T Test.

The comparison between the induced growth is more clearly seen in the Figure, which shows the data from the Table in a two curve fit and dismissed the doses above $160 \mathrm{~Gy}$.

The isolated 80 Gy group values were $9.7 \%$ greater than those seen in the equivalent control group, while the colonized 20 Gy group showed a development only $2.4 \%$ superior to that observed

TABLE

Mean diameter of snails maintained in colonized and isolated groups, after irradiation with ${ }^{60} \mathrm{Co}$ gamma radiation and the slope of the shell diameter rise during 30 days, for each dose. Dose $0 \mathrm{~Gy}$ is the non irradiated (control) group

\begin{tabular}{|c|c|c|c|c|}
\hline \multirow[b]{2}{*}{ Dose (Gy) } & \multicolumn{2}{|c|}{ Colonized groups } & \multicolumn{2}{|c|}{ Isolated groups } \\
\hline & Size $(\%)$ & Slope & Size $(\%)$ & Slope \\
\hline 0 & 124.53 & 0.91 & 132.6 & 1.39 \\
\hline 2.5 & 122.73 & 0.59 & 111.1 & 0.45 \\
\hline 5 & 110.61 & 0.40 & 107.7 & 0.29 \\
\hline 7.5 & 115.15 & 0.50 & 107.7 & 0.21 \\
\hline 10 & 106.67 & 0.21 & 103.3 & 0.11 \\
\hline 15 & 111.11 & 0.43 & 121.4 & 0.83 \\
\hline 20 & 141.67 & 1.16 & 154.8 & 2.09 \\
\hline 25 & 115.79 & 0.69 & 119.4 & 0.72 \\
\hline 30 & 116.67 & 0.54 & 115.3 & 0.54 \\
\hline 35 & 115.52 & 0.46 & 108.2 & 0.28 \\
\hline 40 & 104.69 & 0.29 & 129.8 & 1.02 \\
\hline 45 & 106.67 & 0.21 & 103.3 & 0.11 \\
\hline 50 & 104.48 & 0.22 & 106.7 & 0.18 \\
\hline 55 & 104.48 & 0.16 & 109.7 & 0.34 \\
\hline 60 & 107.46 & 0.28 & 104.8 & 0.17 \\
\hline 80 & 126.92 & 1.15 & 142.3 & 1.62 \\
\hline 160 & 109.43 & 0.33 & 0.0 & -3.61 \\
\hline 320 & 0.00 & -4.89 & 0.0 & -5.09 \\
\hline 640 & 0.00 & -5.06 & 0.0 & -4.83 \\
\hline
\end{tabular}




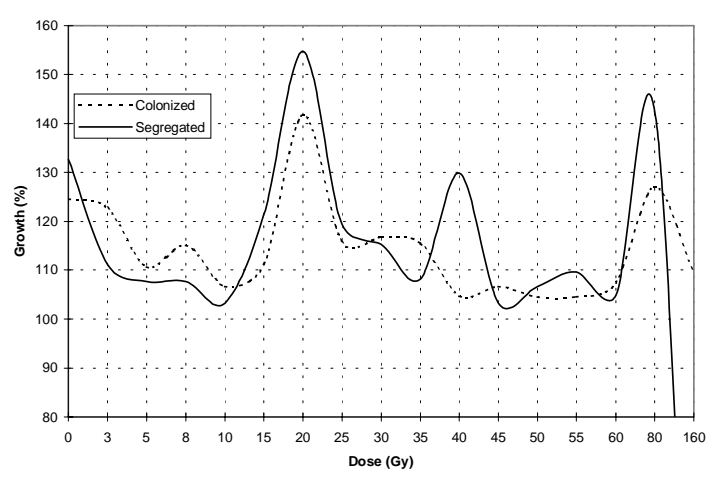

Growth of the snails observed along 30 days after irradiation with gamma rays from ${ }^{60} \mathrm{Co}$ of colonized and isolated (segregated) Biomphalaria straminea.

in control snails. However, at the 20 Gy dose the isolated group values surpassed those of the control group by $22.2 \%$ and the colonized snails attained a growth $17.2 \%$ greater than the control. As stated earlier this suggests the involvement of a window of energy in this phenomenon, as discussed bellow.

\section{DISCUSSION}

The growth of $B$. straminea is reportedly greater when they are in sexual segregation then in colonies (Pessoa \& Martins 1982, Paraense 1986, Rozenberg 1989). The data in the Table support this theory with the shell development of the isolated control group snails estimated as being $8.1 \%$ greater than the colonized control group.

Notwithstanding, we should consider that an increase of lethality occurring in the high doses groups could cause a variation in the snail mean diameter. Thus, after the death of one snail with a large shell, the mean value of the diameter of its group decreases. This fact could explain some peaks of growth such as those observed in the 15, $20,25,40$ e 80 Gy groups. However, in the 30,35, 45, 50,55 and 60 Gy groups, the shell diameter did not present any significant alteration during the observation time. Such findings were also reported by Perlowagora-Szumlewcz (1964) and Carvalho (1992). We are of the opinion that the error caused in the final observation as irrelevant, taking in account the length of the sampling procedure.

The results presented in the Table revealed that growth of the snails irradiated with gamma-rays doses was depressed, except after irradiation with 20 and $80 \mathrm{~Gy}$, where the results surpassed those observed in their control groups. Doses of 20, 40 and 80 Gy raised the ratio colonized/isolated diameter of shells in the groups and the Figure shows curve peaks with higher slopes in the segregated groups than in colonized plots. These effects en- hance the previous supposition (Motta \& Melo $1997 \mathrm{a}, \mathrm{b})$ that there exists some kind of resonance inducing a shaper biological effect as suggested by Lorenz (1950). The Figure revealed a gamma-ray induced depression of $B$. straminea body mass development processes, until the dose of $10 \mathrm{~Gy}$ which was followed by the reversion of this effect, up to $20 \mathrm{~Gy}$. The last dose, however, stimulated more the development of the sexually segregated group, producing a spurt of growth in the body mass, reflected in the increased shell diameter among the isolated snails, probably due to an increase in sexual hormones or by any excitatory mechanism associated with reproductive activity as the expression of a surviving mechanism commencing after doses higher than $10 \mathrm{~Gy}$.

This effect could be linked to a presumed self protective effect in this species, enhancing the hermaphroditic reproductive activity when the animal is suffering radio-ionizing aggression, occurring through the action of some hypothetical hormonal molecular resonance, until the doses close to 20 Gy. Moreover, the behavior observed in both the studied reproductive form groups, as shown in the Table and in the Figure is curious: the doses applied immediately under and above 20, 40 and 80 Gy caused reduction in the snail development. This fact could suggest an excitatory reaction of the metabolic processes, occurring mainly among the 20 Gy irradiated segregated snails and indicates a more sensitive band of energy certainly linked to windows of resonance existing in concerned molecular groups. Finally the ratio diameter/slope of each aforementioned peak in the isolated group was found to be greater, confirming the higher intensity in the growing stimulus of this group.

These findings led us to suppose a marked enhancing effect of the $20 \mathrm{~Gy}$ gamma-rays doses on the growth of the sexually segregated $B$. straminea, as compared with the control group. Ongoing studies are in progress to investigate the observed difference between the groups analyzed here, mainly on the sexual isolation and self fertilization hormonal aspects. RIA techniques will be tested in an attempt to define the hormonal role played in this phenomenon, envisaging a possible future application in the epidemiological control of schistosomiasis.

\section{ACKNOWLEDGEMENTS}

To CPqAM donation of B. straminea snails and to $\mathrm{CNPq}$ for the grants.

\section{REFERENCES}

Carvalho EFNB 1992. Efeitos da Radiação Gama ${ }^{60} \mathrm{Co}$ sobre o Crescimento, Fecundidade, Fertilidade e Sobrevivência de Biomphalaria glabrata (Say, 1818), MSc Thesis, Universidade Federal de Pernambuco, 
Recife, $77 \mathrm{pp}$.

Leal MAM 1976. Marcação Radio-isotópica de Caramujo Vetor da Esquistossomose e sua Utilização em Estudos de Dinâmica de Populações, MSc Thesis, Universidade Federal de Pernambuco, Recife, 54 pp.

Liard F, Chirriboga J, Pellegrino J 1968. Effect of radiation on the reproductive potential of Biomphalaria glabrata. Rev Bras Pesq Med Biol 1: 157-162.

Lorenz E 1950. Some biologic effects of long continued irradiation. Am J Roentgenol Nuc Med 63: 176.

Malta J 1994. Esquistossomose Mansônica, Editora Universitária UFPE, Recife, $274 \mathrm{pp}$.

Melo AMMA 1998. Estudo dos Efeitos da Radiação Gama de ${ }^{60}$ Co sobre Larvas de Biomphalaria glabrata (Say, 1818), Thesis, Instituto de Pesquisas Energéticas e Nucleares da Universidade de São Paulo, São Paulo, 65 pp.

Melo AMMA, Okazaki K, Kawano T 1996, Study of ${ }^{60} \mathrm{Co}$ gamma radiation on Biomphalaria grabrata (Say, 1818) embryos. J Med Appl Malacology 8: 140-141

Motta MA, Melo AMMA 1997a. Fecundity changes induced by low-doses of gamma radiation on Biomphalaria straminea (Dunker, 1848). Mem Inst Oswaldo Cruz 92 : 559-561.

Motta MA, Melo AMMA 1997b. $\mathrm{DL}_{50 / 30}$ of Biomphalaria straminea (Dunker, 1848) after irra- diation with ${ }^{60} \mathrm{Co}$ gamma rays. Bull Inst Malac Tokyo 3: 59-63.

Okazaki K, Andrade HF, Kawano T 1996. Effect of ${ }^{60} \mathrm{Co}$ gamma radiation on Biomphalaria glabrata (Mollusca, Gastropoda) embryos: mortality, malformation and hatching. Braz J Med Biol Res 29: 1057-1067.

Paraense WL 1986. Distribuição dos caramujos no Brasil, p. 117-126. In Modernos Conhecimentos sobre Esquistossomose Mansônica, Vol. 14, Academia Mineira de Medicina, Belo Horizonte.

Paraense WL, Deslandes N 1955. Observations on the morphology of Australorbis glabratus. Mem Inst Oswaldo Cruz 53: 87-103.

Perlawagora AS, Berry EG 1964. Effects of ionizing radiation on Astralorbis glabratus eggs. Exp Parasitol 15: 226-231.

Pessoa SB, Martins AV 1982. Parasitologia Médica. In Amilcar Vianna Martins, Trematódeos Parasitas do Sistema Sangüineo - Schistosoma mansoni, 11th ed., 2nd reprint, Guanabara Koogan, Rio de Janeiro.

Rey L 1967. Parasitologia, 2nd ed. Guanabara Koogan, Rio de Janeiro, $876 \mathrm{pp}$.

Rozemberg B 1989. Fecundidade Comparada de Biomphalaria straminea (Dunker 1848) e Biomphalaria glabrata (Say, 1818) em Laboratórios no Decurso de um Ano, MSc Thesis, Instituto Oswaldo Cruz, Rio de Janeiro, 44 pp. 